\title{
Misconduct charges against Gallo withdrawn after Popovic decision
}

Washington. The Office of Research Integrity (ORI) of the US Department of Health and Human Services last week drew down the curtain on its five-year effort to convict AIDS researcher Robert Gallo of scientific misconduct.

The ORI's action took the form of a terse letter to the appeals board, which has ultimate authority in cases involving the National Institutes of Health. It follows the board's decision the previous week to dismiss charges of misconduct against Gallo's co-researcher, Mikulas Popovic, on the grounds that the evidence produced by ORI did not stand up to legal scrutiny (see Nature 366, 99; 1993).

Aware that it was not able to meet such legal standards at a forthcoming hearing against Gallo, ORI told the appeals board that it felt compelled to withdraw its finding that Gallo deliberately included a false sentence in the key paper identifying what is now known as human immunodeficiency virus (HIV) as the cause of AIDS.

Gallo says he is "delighted" with the dismissal, and that he feels "completely vindicated" by the board's verdict. He says that he now intends to "redouble my efforts in the fight against AIDS and cancer".

The paper was published in the 4 May 1984 issue of Science. Popovic, who worked in Gallo's laboratory at the US National Cancer Institute and was the first researcher to grow the virus in sufficient quantity to develop a blood test, was the lead author.

More than a year ago, ORI found Popovic guilty on four counts of scientific misconduct, based on statements made in the paper. After a 12-day hearing, however, and an extensive line-by-line analysis, the appeals board exonerated Popovic, saying that it had expected to find "at least a residue of palpable wrongdoing", but had not done so.

Popovic's appeals hearing was the first occasion during which the evidence for and against the charge of misconduct was presented in open court. It was an environment that allowed his attorney, Barbara Mishkin, to cross-examine ORI's witnesses and publicly present evidence on Popovic's behalf.

The appeals board eventually decided that ORI could not prove either that the Science paper contained untrue statements, or that it contained "intentional falsifications"

ORI says that it withdrew its case against Gallo because the appeals board has set unreasonably high standards of proof of scientific fraud. Chief among them is the idea, based on legal concepts of evidence, that proof of fraud requires evidence of intent, and that someone has been defrauded.

As the essential data in the Science paper were never challenged, ORI was left to prove that a sentence which, in its view, failed to describe accurately how scientists in Gallo's laboratory used a virus from the Institut Pasteur in Paris was deliberately intended to mislead

Gallo, who had briefly grown the French virus in his laboratory (but says it did not grow well) wrote: "However, it is possible that this is due to insufficient characteriza-

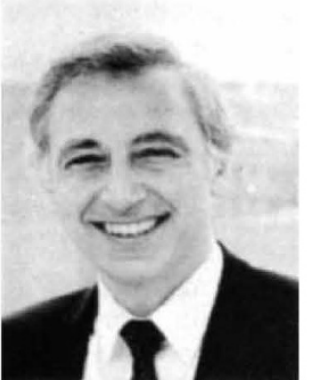

Robert Gallo tion of LAV [the French virus] because the virus has not yet been transmitted to a permanently growing cell line for true isolation and therefore has been difficult to obtain in quantity."

ORI said that this sentence was misleading, as

Gallo's laboratory notebooks show that LAV had in fact been successfully grown, even though ORI has conceded that the notebooks do not show LAV growing long or vigorously.

Gallo denies ORI's interpretation. $\mathrm{He}$ claims that the sentence was intended to indicate that the French researchers had not grown LAV in a permanent cell line, and therefore could not obtain it in quantity.
Gallo says he believed that the virus that did grow well in his own laboratory - identified as HTLV-III - was distinct from LAV.

Several years after the paper was published, tests by Gallo and by Luc Montaigner of Pasteur proved that the disputed virus was a contaminant that originated in France, but that both laboratories were unaware of this at the time of their original studies.

ORI officials have argued that their dismissal of the Gallo case is based on legal technicalities rather than its merits. Interestingly, its critics include AIDS activists from Project Inform in San Francisco.

Martin Delaney, director of Inform, claims that this is an attempt by ORI to save face by suggesting the failure of its case is due to a new definition of scientific fraud. "That is completely untrue", says Delaney, pointing out that the appeals board's explicitly tested the Popovic and Gallo cases against a definition of misconduct adopted by the department in 1989.

ORI is now working on revised guidelines that will allow a scientist to be convicted of fraud only is he or she knew "or should have known" that a sentence in a manuscript might be misleading - an approach that opens up a whole new argument about whether scientists should be legally held to more stringent standards of behaviour than those applied to other academics.

Barbara J. Culliton

\section{French keeps up claims to AIDS patent}

Paris. France has repeated its determination to obtain from the United States the credit and the royalties for the discovery of the AIDS virus, following last week's decision by the US Office of Research Integrity to terminate scientific misconduct proceedings against Robert Gallo (see above). "The decision has no bearing on our position," said both the Ministry of Higher Education and the Pasteur Institute in separate statements.

France argues that allegations of scientific misconduct have always been secondary to the wider public policy issues which, it claims, have been raised by the dispute between Gallo and researchers at the Pasteur Institute in Paris over who can claim to have discovered the virus.

French officials claim that everyone including Gallo - now agrees that the so-called HTLV-III virus used by Gallo to make the US AIDS test was in fact the LAV virus previously isolated by researchers at the Pasteur Institute. (The institute also emphasizes that it supplied Gallo with the LAV virus on the explicit condition that he did not use it for commercial purposes).

This interpretation first emerged two years ago, following investigations by John Crewdson, a reporter with the Chicago Tribune. But the United States has refused to renegotiate the 1987 agreement with France that provides for an equal split of the $\$ 8$ million or so annual royalties from the patent for the AIDS blood test. The agreement was based on the understanding that both Gallo and the French had independently discovered two separate strains of the AIDS virus.

This week, Weil Gotshal and Manges, the Washington law firm representing the Pasteur Institute, said that the US Department of Health and Human Services and the National Institutes of Health were bound by "conscience" and their "commitment to scientific integrity" to "bring the 1987 position of the US government into conformance with what everyone now understands to be the truth." However the Clinton administration has previously indicated that it has no intention of re-opening negotiations with France.

Declan Butle 